\title{
KONTRIBUSI KOMITMEN GURU DAN KEPEMIMPINAN KEPALA SEKOLAH TERHADAP DISIPLIN KERJA GURU PENELITIAN KORELASIONAL DI MADRASAH ALIYAH NEGERI 2 BATUSANGKAR KABUPATEN TANAH DATAR
}

\author{
Imawati \\ Pegawai Kantor Kementerian Agama Kabupaten Tanah Datar
}

1262

\begin{abstract}
This correlational study was aimed at revealing the contribution of teachers' commitment and school leadership to the teachers' discipline at State Islamic High School (MAN) 2 Batusangkar. The results showed that 1) the teachers' commitment contributed to the teachers' discipline $62.8 \%$. It means that the teachers' commitment needs to be improved; 2) the principal's leadership contributed significantly to the teachers' discipline $50.4 \%$. It means that the contribution of school leadership needs to be improved; and 3) the teachers' commitment and school leadership together significantly contributed to the teachers' discipline $77.5 \%$ and $22.5 \%$ were influenced by other variables, it was not examined in this study.
\end{abstract}

Keywords: Teachers' Commitment, Principal Leadership and Teachers' discipline

\section{PENDAHULUAN}

Guru merupakan komponen pendidikan yang sangat berpengaruh dalam meningkatkan kualitas pendidikan. Tanpa guru, komponen kurikulum, sumber belajar, sarana dan prasarana, dan iklim pembelajaran menjadi sesuatu yang tidak berarti bagi kehidupan peserta didik. Agar dapat melaksanakan tugas pokok dan fungsinya dengan baik, guru dituntut mempunyai disiplin kerja yang tinggi, karena disiplin kerja merupakan salah satu modal utama yang amat menentukan dalam mencapai tujuan suatu lembaga/organisasi.

Sesuai dengan yang diungkapkan oleh Sucipto (2002) bahwa disiplin kerja personil sangat menentukan masa depan organisasi dan pencapaian target yang diharapkan organisasi begitu juga halnya dengan guru. Fathoni (2006: 127) menyatakan bahwa faktor-faktor yang mempengaruhi disiplin kerja guru adalah 1) tujuan dan kemampuan personil; 2) keteladanan pimpinan; 3) kompensasi; 4) keadilan; 5) supervisi; 6) sanksi hukuman; 7) ketegasan; dan 
8) hubungan kemanusiaan. Selanjutnya Wursanto (1978) menyatakan bahwa disiplin kerja guru dipengaruhi oleh tingkat komitmen kerja dan adanya imbalan yang adil.

Berdasarkan beberapa pendapat di atas dapat disimpulkan bahwa faktor-faktor yang mempengaruhi disiplin kerja guru antara lain 1) kepemimpinan, 2) supervisi, 3) insentif, 4) sanksi hukuman, 5) komitmen, 6) hubungan Interpersonal, 7) keadilan, dan 8) ketegasan. Faktor Komitmen diri pada seorang guru tumbuh dan berkembang secara positif, memungkinkannya dalam melaksanakan tugas dengan penuh tanggung jawab, bersemangat dan menyelesaikan berbagai tugas yang dilaksanakannya dengan baik serta mematuhi aturan-aturan yang ditetapkan oleh sekolah. Dengan semakin baiknya komitmen guru membuka peluang bagi guru untuk memperbaiki disiplin kerjanya. Dengan demikian pada gilirannya peningkatan mutu pendidikan dapat diwujudkan.

Sedangkan faktor kepemimpinan kepala sekolah merupakan usaha kepala sekolah untuk mempengaruhi, mendorong, menggerakan dan mengarahkan unsurunsur sekolah dan pihak yang terkait dengan sekolah dalam mencapai tujuan pendidikan. Kepala sekolah merupakan salah satu komponen yang berpengaruh dalam meningkatkan disiplin kerja guru. Dengan demikian kepemimpinan kepala sekolah diduga turut berkontribusi terhadap disiplin kerja guru.

Imron (1995:183) menyatakan bahwa disiplin adalah suatu keadaan di mana segala sesuatu berada dalam keadaan teratur, tertib, dan menurut semestinya, serta tidak terjadi pelanggaran. Disiplin kerja guru sangat penting untuk dilaksanakan, karena untuk mencapai tujuan pendidikan yang telah ditetapkan dalam suatu lembaga/organisasi sangat didukung oleh personil yang memiliki disiplin kerja yang tinggi.

Guru yang disiplin dalam melaksanakan tugasnya akan membuat perangkat pembelajaran sesuai dengan aturanaturan yang diberlakukan, melaksanakan pembelajaran dan membimbing siswa belajar secara bertanggung jawab dan disiplin sehingga siswa dapat belajar secara optimal yang pada gilirannya mutu pendidikan akan menjadi baik. Oleh sebab itu disiplin guru dalam melaksanakan tugas perlu menjadi perhatian kepala sekolah agar tetap terbina dengan baik, sehingga tujuan sekolah dan mutu pendidikan semakin meningkat.

Komitmen merupakan janji (keterikatan) seseorang yang diiringi dengan loyalitas, tanggung jawab dan rasa keikhlasan yang tinggi untuk melakukan sesuatu. Jadi 
dengan adanya komitmen yang tinggi, maka seorang guru akan lebih disiplin dalam melaksanakan tugasnya, karena dia telah merasa terikat dengan janjinya. Oleh karena itu komitmen terhadap tugas diduga berdampak terhadap disiplin kerja.

Gauzali (2000) mengemukakan bahwa karyawan yang mempunyai komitmen yang tinggi pada organisasi akan bersemangat, berdisiplin tinggi dan sekaligus mereka berkesempatan untuk meningkatkan profesionalisme dan produktivitas kerja. Selanjutnya Hendiyat (1998) menyatakan bahwa seorang bawahan yang mempunyai komitmen tinggi pada tugas atau lembaga, biasanya dengan menunjukkan kepatuhan, rasa hormat, kesetiaan serta displin yang tinggi. Hal ini diperkuat dengan hasil penelitian Hendra (2005) yang menyimpulkan bahwa komitmen pegawai berpengaruh positif terhadap disiplin kerja pegawai.

Apabila kepemimpinan kepala sekolah terlaksana secara optimal maka akan mampu mengarahkan dan membimbing guru bekerja sesuai dengan aturan-aturan dan norma-norma yang berlaku sehingga guru akan terbiasa bekerja secara teratur dan disiplin. Kepemimpinan kepala sekolah yang efektif akan menunjang peningkatan disiplin kerja guru.
Berdasarkan uraian di atas bahwa kepemimpinan kepala sekolah diyakini akan berkontribusi terhadap disiplin kerja guru. Artinya semakin baik kepemimpinan kepala sekolah, maka akan meningkatkan disiplin kerja guru.

Disiplin kerja merupakan suatu keadaan tertib dan teratur yang dimiliki oleh guru dalam bertugas di sekolah, tanpa adanya pelanggaran-pelanggaran terhadap aturan atau kaidah-kaidah yang telah disepakati. Kedisiplinan guru dalam bertugas diduga dapat dipengaruhi oleh komitmen tidaknya dia dalam bekerja, karena komitmen pada tugas merupaka seorang guru selaku tenaga profesional dalam melaksanakan tugasnya sebagai pendidik. Sebab guru yang memiliki komitmen tinggi diduga dapat berdampak terhadap kedisiplinannya dalam melaksanakan tugasnya dan dia akan berusaha untuk aktif dengan penuh rasa tanggung jawab dalam tugas-tugasnya.

Menurut Piet (1994) komitmen merupakan kecendrungan dalam diri seseorang untuk merasa aktif dengan penuh rasa tanggung jawab. Jadi seorang guru yang memiliki komitmen dalam tugasnyatugasnya, dia akan bertanggung jawab untuk melaksanakan tugas-tugas tersebut dengan sebaik-baiknya, dengan arti kata dia akan selalu memperhatikan kedisiplinan. 
Begitu juga dengan kepemimpinan kepala sekolah. Kepemimpinan kepala sekolah akan menimbulkan kemauan yang kuat, semangat, dan kepercayaan diri para guru dalam melaksanakan tugas yang diembannya.

Komitmen dan kepemimpinan kepala sekolah dilaksanakan dengan baik dan dikembangkan secara optimal, maka akan menjadikan guru dalam melaksanakan tugasnya dengan penuh rasa tanggung jawab. Hal ini akan berimplikasi pada terwujudnya peningkatan disiplin kerja guru.

Komitmen guru adalah perjanjian guru dengan dirinya sendiri untuk melaksanakan tugasnya dengan sungguh-sungguh dan penuh rasa tanggung jawab serta terlibat aktif dalam pencapaian tujuan organisasi. Indikator yang digunakan sebagai komitmen guru adalah: a) kepedulian terhadap tugas, b) bersemangat melaksanakan tugas, c) siap berkorban, dan d) menyediakan waktu dan tenaga untuk membantu siswa. (Piet 1994, Gauzali 2000, Fathoni 2006, Bafadal 2004).

Kepemimpinan kepala Sekolah adalah orang yang mempunyai wewenang untuk mempengaruhi dan menggerakkan guru, staf, siswa, orang tua siswa, dan pihak lain yang terkait untuk berperan serta guna mencapai tujuan yang telah ditetapkan sekolah yang dipimpinnya. Indikator Kepemimpinan kepala sekolah adalah: 1) mengarahkan guru, 2) mendorong guru, 3) memfasilitasi kegiatan sekolah, 4) membimbing guru dan 5) memberikan keteladanan kepada guru (Mulyasa, 2007)

\section{METODE PENELITIAN}

Penelitian ini bersifat kuantitatif dengan metodologi penelitian korelasional, Pendekatan penelitian korelasional bertujuan ingin mengetahui kontribusi antara komitmen guru dan kepemimpinan kepala sekolah terhadap disiplin kerja guru di lembaga pendidikan Islam yakni Madrasah Aliyah Negeri (MAN) 2 Batusangkar. Penelitian korelasional menurut (Hanafi: 2011:124) adalah penelitian yang bertujuan untuk mengukur tentang ada atau tidak adanya hubungan antara dua atau lebih variabel yang diajukan oleh peneliti dengan ukuran yang valid dan reliabel.

Metode penelitian yang digunakan dalam penelitian ini dengan menggunakan pendekatan korelasional dengan metode sensus karena pengambilan sampel penelitian dari satu populasi dengan menggunakan kuesioner sebagai alat pengumpul data yang pokok. Pendekatan ini digunakan untuk menguji kontribusi antara variabel satu dengan yang lainnya (variabel bebas dengan variabel terikat) (Sugiyono, 2011).

Model korelasional ini dipilih karena penelitian ini bertujuan untuk 
mengungkapkan besarnya kontribusi satu variabel terhadap variabel lain, dan untuk mengungkap kontribusi masing-masing variabel serta kontribusi variabel bebas yaitu komitmen guru dan kepemimpinan kepala sekolah terhadap variabel terikat yaitu disiplin kerja guru.

\section{HASIL PENELITIAN DAN PEMBAHASAN}

1. Kontribusi komitmen guru terhadap disiplin kerja guru sebesar $62,8 \%$, berarti komitmen guru cukup berkontribusi dalam pelaksanaan disiplin kerja guru di MAN 2 Batusangkar. Maka perlu untuk ditingkatkan ketaraf baik atau bahkan lebih baik. Besarnya kontribusi tersebut memberikan gambaran bahwa komitmenguru memiliki pengaruh yang berarti terhadap peningkatan disiplin kerja guru. Hal ini sejalan dengan pendapat Gouzali (Sudjana, 2004) yang menyatakan bahwa komitmen kerja merupakan faktor yang ikut mempengaruhi disiplin kerja seorang karyawan (guru). Gouzali menegaskan bahwa pekerja yang memiliki komitmen yang baik akan tergambar dari tingginya disiplin, semangat dan gairah kerja mereka dalam melakukan pekerjaan. Dapat dimaknai bahwa mereka yang memiliki komitmen yang tinggi, akan memiliki disiplin yang tinggi pula terhadap pekerjaannya (Sudjana, 2004). Sudjana (2004) menyatakan bahwa komitmen merupakan modal utama bagi seorang guru dalam hal melaksanakan pekerjaan yang baik. Komitmen dengan pertimbangan faktor ini merupakan pendorong utama setiap guru untuk lebih aktif, kreatif, inovatif, dan partisipatif dalam melaksanakan tugas keprofesiannya sesuai ketentuan yang berlaku sebagai tenaga profesi kependidikan. Dapat dijelaskan bahwa dengan adanya komitmen guru yang mendalam, tentunya guru akan mau menyelesaikan tugasnya dengan sebaikbaiknya, sehingga akan terwujud prilaku untuk melakukan pekerjaan dengan baik pula, yang berwujud dalam bentuk disiplin kerja.

Gauzali (2000: 288) menyatakan bahwa pembinaan disiplin terhadap pekerja dapat berupa 1) penciptaan peraturan dan tata tertib yang harus dilaksanakan oleh pekerja, 2) menciptakan dan memberi sanksi-sanksi bagi pelanggar disiplin, serta 3) melakukan pembinaan disiplin melalui pelatihan-pelatihan kedisiplinan yang terus menerus. Guru yang memiliki disiplin kerja yang tinggi dapat terlihat dari sikapnya dalam melaksanakan 
pekerjaan yang penuh dengan rasa tanggung jawab, serta memperhatikan efisiensi dan efektivitas dalam pelaksanaan pekerjaannya tersebut. Dalam artian, guru yang disiplin kerjanya tinggi akan terdorong untuk melaksanakan tugasnya dengan baik. Dengan demikian dapat dinyatakan bahwa untuk meningkatkan disiplin kerja guru dapat dilakukan melalui peningkatan komitmen guru itu sendiri.

2. Kontribusi kepemimpinan Kepala Sekolah terhadap disiplin kerja guru sebesar 50,4\%, artinya kepemimpinan kepala sekolah cukup berkontribusi dalam pelaksanaan disiplin kerja guru pada MAN 2 Batusangkar, Maka perlu untuk ditingkatkan ke taraf baik atau bahkan lebih baik.

Kepemimpinan Kepala Sekolah dalam penelitian ini juga memiliki hubungan yang signifikan dan memberi kontribusi yang berarti terhadap disiplin kerja guru. Gauzali (2000) menyatakan bahwa salah satu cara yang dapat dilakukan untuk meninggkatkan disiplin kerja yang dimiliki oleh pekerja (guru) adalah melalui penciptaan hubungan yang harmonis, dimana hubungan yang harmonis dapat terwujud melalui kounikasi interpersonal yang baik. Jadi dapat dimaknai bahwa kepemimpinan kepala sekolah ikut mempengaruhi disiplin kerja guru. Selanjutnya Gauzali (2000: 328) menegaskan bahwa kepemimpinan kepala sekolah yang baik cenderung membuat seseorang saling mempengaruhi dan memiliki kegairahan atau keinginan yang kuat untuk melaksanakan tanggung jawabnya. Dengan demikian, dapat dinyatakan bahwa kepemimpinan kepala sekolah ikut menjadi penentu tinggi rendahnya disiplin kerja, walaupun pengaruhnya relatif lebih kecil.

3. Kontribusi secara bersama-sama antara komitmen guru dan kepemimpinan Kepala Sekolah terhadap disiplin kerja guru sebesar $77,5 \%$, artinya kedua variabel cukup berkontribusi dalam pelaksanaan disiplin kerja guru di MAN 2 Batusangkar dan hanya 22,5\% dipengaruhi oleh variabel lain. Maka perlu untuk ditingkatkan ketaraf baik atau bahkan lebih baik.

Analisis data menunjukkan bahwa displin kerja guru dipengaruhi oleh komitmen guru dan kepemimpinan kepala sekolah, baik secara sendiri-sendiri maupun bersama-sama. Komitmen 
dan kepemimpinan Kepala Sekolah merupakan dua faktor yang sangat penting karena dapat mempengaruhi tinggi rendahnya disiplin kerja guru. Komitmen yang tinggi dan didukung oleh kepemimpinan kepala sekolah yang baik, akan dapat lebih meningkatkan disiplin kerja guru menjadi lebih baik.

Dengan demikian, untuk meningkatkan disiplin kerja guru dapat dilakukan dengan berupaya meningkatkan komitmen agar lebih baik dan berusaha memperbaiki kepemimpinan kepala sekolah agar lebih baik pula, sehingga diharapkan disiplin kerja guru akan semakin baik. Uraian di atas menunjukkan bahwa faktor komitmen dan kepemimpinan Kepala Sekolah merupakan dua faktor penting yang dapat digunakan untuk meningkatkan disiplin kerja guru.

\section{KESIMPULAN}

Penelitian ini dapat disimpulkan bahwa komitmen guru dan kepemimpinan kepala sekolah baik secara sendiri-sendiri maupun bersama-sama secara signifikan berkontribusi cukup kuat atau sedang terhadap disiplin kerja guru pada MAN 2 Batusangkar Kabupaten Tanah Datar. Maka kedepannya perlu untuk ditingkatkan ke taraf kuat atau baik bahkan sangat kuat atau lebih baik sehingga disiplin kerja guru MAN 2 Batusangkar terwujud ketaraf baik bahkan lebih baik.

\section{SARAN}

1. Bagi Guru agar dapat meningkatkan komitmen kerja dengan cara meningkatkan kepedulian, rasa tanggung jawab, loyal terhadap tugas yang diemban, kemudian mengerjakannya secara tulus dan ikhlas.

2. Kepala Sekolah agar dapat meningkatkan Disiplin kerja guru melalui kepemimpinan dan keteladanan yang baik.

3. Dinas Pendidikan dan Kementerian Agama Kabupaten Tanah Datar agar dapat melakukan pembinaan profesi guru secara terus menerus (continuous professional development), yaitu melalui wadah guru yang sudah ada seperti Kelompok Kerja Guru (KKG).

4. Hasil penelitian ini menunjukkan bahwa ada faktor lain yang ikut berkontribusi terhadap Disiplin Kerja guru selain Komitmen guru dan Kepemimpinan Kepala Sekolah. Bagi peneliti selanjutnya disarankan untuk menggali lebih dalam faktor-faktor yang belum diteliti pada penelitian ini. 
KEPUSTAKAAN ACUAN

Bafadal, Ibrahim. (2004). Peningkatan Profesionalisme Guru Sekolah Dasar. Jakarta: PT Bumi Aksara.

Fathoni, Abdurrahmat. (2006). Manajemen Sumber Daya Manusia. Jakarta: Rineka Cipta.

Gauzali, Saydam. (2000). Menajemen Sumber Daya Manusia: Pendekatan Makro. Jakarta: Djambatan.

Hanafi, Abdul Halim. (2011). Metode Penelitian Kependidikan. Batusangkar: STAIN Batusangkar Press.

Hendiyat, Soetopo. (1998). Kepemimpinan dan Supervisi Pendidikan. Jakarta: Bina Aksara.

Hendra. (2005). Pengaruh Pengawasan Atasan, Pemberian insentif dan Komitmen terhadap Disiplin Kerja Pegawai di PDAM Kota Padang. Padang: Tesis UNP
Imron, Ali (1995). Pembinaan Guru di Indonesia. Malang:Pustaka Jaya.

Mulyasa, E. (2007). Standar Kompetensi dan Sertifikasi Guru. Bandung: PT Remaja Rosdakarya.

Piet. A. Sahertian. (1994). Profil Pendidikan Nasional. Yogyakarta: Andi Offset.

Sucipto, Budi W. (2002). Paradigma Baru Manajemen Sumber Daya Manusia. Yogyakarta: Amara Books.

Sujana, Nana. (2004). Tuntunan Penyusunan Karya Ilmiah. Bandung: Sinar baru Algesindo.

Sugiyono (2011). Metode Penelitian Kuantitatif, Kualitatif dan Mixed Method, Bandung: Alfabeta.

Wursanto. (1978). Manajemen Personalia. Jakarta: Pustaka Dian. 